(c) American Dairy Science Association, 2004.

\title{
Combined Use of Chymosin and Protease from Cryphonectria parasitica for Control of Meltability and Firmness of Cheddar Cheese
}

\author{
S.-Y. Kim, ${ }^{1}$ S. Gunasekaran, ${ }^{2}$ and N. F. Olson ${ }^{1}$ \\ ${ }^{1}$ Department of Food Science and \\ ${ }^{2}$ Department of Biological Systems Engineering \\ University of Wisconsin-Madison, Madison 53706
}

\begin{abstract}
The combined use of chymosin and Cryphonectria parasitica protease was evaluated for manufacturing Cheddar cheese at different chymosin-to-C. parasitica protease ratios of 1:0, 0:1, 67:33, and 33:67. The degree of proteolysis over time was affected by the coagulant type. Proteolysis was thought to be the main cause of changes in functional properties of Cheddar cheeses. The meltability and hardness of cheese made with $100 \%$ C. parasitica enzyme was the highest, but it was high in bitterness. The chymosin-to-C. parasitica ratio between 0:1 to 67:33 was found suitable to independently control Cheddar cheese meltability and hardness without a significant level of bitterness.
\end{abstract}

(Key words: coagulant, firmness, meltability, proteolysis)

\section{INTRODUCTION}

The proteolytic agents in cheese generally originate from the following sources: coagulant, milk, and starter and nonstarter bacteria. Visser (1977) and Visser and de Groot-Mostert (1977) concluded: 1) the coagulant is responsible for the initial hydrolysis of caseins and the production of most of the water-soluble or $\mathrm{pH} 4.6$-soluble $\mathrm{N}$ in Gouda-type cheese and 2) the actions of indigenous milk and starter proteases are less important at this level of proteolysis. However, the production of small peptides and amino acids is due primarily to the action of starter bacteria or their enzymes.

Chymosin (E.C. 3.4.23.4) is the principal protease used for cheese making. In addition to cleaving the $\mathrm{Phe}_{105}-\mathrm{Met}_{106}$ bond of $\kappa$-CN, chymosin also readily hydrolyses certain peptide bonds in $\alpha_{\mathrm{s} 1}-\mathrm{CN}, \alpha_{\mathrm{s} 2}-\mathrm{CN}$, and $\beta$-CN under appropriate conditions (McSweeney and Fox, 1993). Recombinant chymosins, expressed by As-

Received April 7, 2003

Accepted July 1, 2003

Corresponding author: S. Gunasekaran; e-mail: guna@wisc.edu pergillus niger var. awamori, Kluveromyces marxianus var. lactis and Escherischia coli, are widely used for cheese making in many countries. Recombinant chymosins usually contain only one generic variant, while calf rennet may contain three chymosin variants, A, B, and $\mathrm{C}$, as well as bovine pepsin. Possible differences in specificity between chymosin variants have not been reported (Green et al., 1985; O'Sullivan and Fox, 1991).

The milk-clotting enzyme Cryphonectria parasitica causes considerably greater hydrolysis of $\beta$-CN during storage of Mozzarella cheese as compared to veal rennet or the milk-clotting enzyme from $R$. miehei (Yun et al., 1993). The change in cheese properties during storage is related to the combined effects of hydrolysis of $\alpha_{\mathrm{s} 1^{-}}$ $\mathrm{CN}$ and $\beta$-CN (Tam and Whitaker, 1972; Vanderpoorten and Weckyx, 1972).

De Jong (1977) related the disappearance of intact $\alpha_{\mathrm{s} 1}-\mathrm{CN}$ to the magnitude of softening during maturation of Meshanger, a soft Dutch cheese. Decreases in percent compression and fracture force, as measured by uniaxial compression test, of Cheddar cheese were related to the disappearance of $\alpha_{\mathrm{s} 1}$-CN during maturation but were not related to degradation of $\beta$-CN (Creamer and Olson, 1982). Bogenrief and Olson (1995) showed that hydrolysis of $\beta$-CN was greatly enhanced in Cheddar cheese by using the clotting enzyme from $C$. parasitica, but the level of hydrolysis of $\alpha_{\mathrm{s} 1}$-CN was similar to that in cheese made with chymosin. The degree of meltability was closely correlated with the extent of $\beta$-CN hydrolysis in cheese but not with hydrolysis of $\alpha_{\mathrm{s} 1}-\mathrm{CN}$. Rheological characteristics of cheese are complex during maturation and are influenced initially by hydrolysis of $\alpha_{\mathrm{s} 1} \mathrm{CN}$ and $\beta$-CN and subsequently by more extensive proteolysis.

Cryphonectria parasitica protease is more proteolytic than $M$. miehei protease or chymosin, but the casein substrate differs with coagulant type. Proteolysis of both $\alpha_{\mathrm{s} 1}-\mathrm{CN}$ and $\beta$-CN occurs in Mozzarella cheese made with C. parasitica protease during storage at $4^{\circ} \mathrm{C}$, but $\alpha_{\mathrm{s} 1}-\mathrm{CN}$ is hydrolyzed preferentially in cheeses made with chymosin and $M$. miehei protease (Yun et al., 1993). 
Table 1. Ratios and amounts of chymosin and C. parasitica proteinase used for manufacturing four Cheddar cheeses.

\begin{tabular}{|c|c|c|}
\hline $\begin{array}{l}\text { Cheese } \\
\text { Type }\end{array}$ & $\begin{array}{l}\text { Chymosin:C. parasitica } \\
\text { Enzyme Ratio Used }\end{array}$ & $\begin{array}{l}\text { Amount of } \\
\text { enzyme used } \\
\text { ( } \mu \mathrm{L} / \mathrm{kg} \text { of milk), } \\
\text { Maxiren:Sure-curd }\end{array}$ \\
\hline A & $1: 0$ & $75: 0$ \\
\hline B & $0: 1$ & $0: 49$ \\
\hline $\mathrm{C}$ & $67: 33$ & $50: 16$ \\
\hline D & $33: 67$ & $24: 32$ \\
\hline
\end{tabular}

Our objective was to investigate the combined use of chymosin and the protease from C. parasitica to regulate relative hydrolysis of $\alpha_{\mathrm{s} 1}-\mathrm{CN}$ and $\beta$-CN during aging of Cheddar cheese to independently control its firmness and meltability while controlling undesirable levels of bitterness associated with high levels of $C$. parasitica enzyme.

\section{MATERIALS AND METHODS}

\section{Cheese Making}

Four types of Cheddar cheese were made with different chymosin-to-C. parasitica protease ratios (Table 1) at the University of Wisconsin Dairy Processing Plant. Four vats of each cheese were made and samples were drawn from each vat as replicate measurements. The coagulants used were double strength cloned chymosin derived from Kluyveromyces lactis (Maxiren, Gist-brocades, King of Prussia, PA) and triple strength C. parasitica carboxyl proteinase (Sure-curd, Gist-brocades). Raw whole milk was pasteurized at $73.3^{\circ} \mathrm{C}$ for $16 \mathrm{~s}$ and stored overnight at $3^{\circ} \mathrm{C} ; 246-\mathrm{kg}$ lots of milk were then pumped into each of four cheese vats, heated to $43.3^{\circ} \mathrm{C}$, and cooled to $32.2^{\circ} \mathrm{C}$. A commercial strain of Lactococcus lactis ssp. lactis (Marschall Product, RhonePoulenc, Inc., Madison, WI) which was grown in $8 \%$ solids. Phase 4 medium (Marschall Product, RhonePoulenc, Inc.) was added to the milk at a rate of $0.65 \%$ (wt/wt). The milk was ripened for $40 \mathrm{~min}, \mathrm{CaCl}$ solution (Marschall Product, Rhone-Poulenc, Inc.) was added to milk at the rate of $0.40 \mathrm{~mL} \mathrm{CaCl} / \mathrm{kg}$ milk, and the coagulant was added 5 min later. The amount and ratios of the coagulant added for different cheeses are listed in Table 1 . After cutting with $0.64-\mathrm{cm}$ wire knives, the curd was allowed to heal for $5 \mathrm{~min}$ and then gently stirred mechanically for $5 \mathrm{~min}$. The temperature was raised gradually to $38.3^{\circ} \mathrm{C}$ in $30 \mathrm{~min}$ and half of the experimental vats were heated to $44^{\circ} \mathrm{C}$, held for $5 \mathrm{~min}$, and then cooled to $38.3^{\circ} \mathrm{C}$. All vats were maintained at $38.3^{\circ} \mathrm{C}$ until the curd reached a $\mathrm{pH}$ of $6.2 \pm 0.03$. Then, whey was drained, curd was allowed to mat, the curd block was cut into smaller slabs which were turned and stacked for cheddaring before being milled when the $\mathrm{pH}$ reached $5.55 \pm 0.03$. Flake salt was added $15 \mathrm{~min}$ later at a rate of $3 \mathrm{~g} / \mathrm{kg}$ of milk in three separate additions 5 min apart. Curd was put into 9-kg rectangular stainless-steel hoops and pressed at ambient temperatures under low pressure for $20 \mathrm{~min}$ and at higher pressure for $3 \mathrm{~h}$. The blocks of cheese were then vacuumsealed in barrier bags (VF-400, Vilutis and Co., Frankfort, IL) and stored at $7^{\circ} \mathrm{C}$ throughout the aging period.

\section{Cheese Composition}

Moisture content was determined gravimetrically by drying cheese samples in a vacuum oven at $100^{\circ} \mathrm{C}$ for $5 \mathrm{~h}$. Fat was measured by the Babcock method (Bradley et al, 1992), salt concentration was determined coulometrically (Johnson and Olson, 1985) with a Chloride Analyzer 926 (Corning Glass Works, Medfield, MA), and $\mathrm{pH}$ was measured by the gold electrode/quinhydrone method (van Sylke and Price, 1979). Protein was determined by the Kjeldahl method (Richardson and Marshall, 1985).

\section{Analysis of Protein Hydrolysis}

A standard procedure was used to prepare ureaPAGE gels (Andrews, 1983; Shalabi and Fox, 1987). An SE600 Vertical Slab Gel Unit (Hoefer Scientific, San Francisco, California) was used for gel electrophoresis. Several modifications were made to these two procedures. The potential was kept at $280 \mathrm{~V}$ for the entire electrophoresis run instead of increasing it to $25 \mathrm{~V} / \mathrm{cm}$ when the tracking dye reached the separating gel. A better image of bands on the gels was obtained when: 1) the amount of cheese sample was decreased to 10 $\mathrm{mg}$ (from $100 \mathrm{mg}$ ) and 2) 3 to $10 \mu \mathrm{mL}$ of sample was loaded onto each gel lane instead of $40 \mu \mathrm{mL}$ as specified in the procedure. Glycerol was added to the sample buffer instead of directly to the sample.

The tracking dye was made up as an aqueous solution of bromophenol blue $(50 \mathrm{mg} / 100 \mathrm{~mL}$ of water) and was added to the sample buffer rather than to the sample. The ammonium persulfate concentration was increased by $50 \%$ to hasten the polymerization of the separating gel. The gel was prerun at $28 \mathrm{~V}$ for $60 \mathrm{~min}$ prior to sample loading. Samples in sample buffer were transferred to a boiling water bath, and the contents were stirred vigorously for $5 \mathrm{~min}$. After cooling to room temperature, $10 \mu \mathrm{mL}$ from each vial was loaded onto a polyacrylamide gel $(20 \%)$. The urea-PAGE gel was rinsed in deionized water, soaked overnight in the bromophenol blue solution (Blakesley and Boezi, 1977) with constant agitation, rinsed again, and soaked for 1 $\mathrm{h}$ in a $2 \%$ glycerol aqueous solution with agitation (to 
minimize gel cracking during drying). It was then dried between two sheets of prewetted cellophane stretched out on a frame (Hoefer Pharmacia Biotech, Inc., San Francisco, CA). A constant jet of warm air was blown onto the cellophane sheets (SE 1200 Easy Breeze Air Gel Dryer, low heat setting, Hoefer Scientific Instruments). The gels were then quantified with a laser densitometer. The intensity of individual casein bands for cheeses was expressed as percentage reduction from the bands of $\alpha$-CN and $\beta$-CN lyophilized powders purchased commercially (Sigma-Aldrich Corp., St. Louis, MO) and was obtained as an average of three gels per vat of cheese. The proteolysis was also determined by measuring the $12 \%$ TCA soluble nitrogen according to the procedures of Bynum and Barbano (1985).

\section{Thermal Meltability}

Meltability was measured according to the modified tube method (Bogenrief and Olson, 1995) using 32-mm diameter tubes, placed in a $95^{\circ} \mathrm{C}$ water bath. The tubes were laid horizontally in the water bath to allow $3-\mathrm{cm}$ high $\times 2$-cm diameter cheese cylinders to melt and flow. The distance in millimeters that the leading edge of a cylinder of cheese flowed in 5 min was reported as the meltability. Each test was replicated five times.

\section{Flowability}

A variation of the above tube test was performed to determine cheese flowability. Cheese cylinders $(2-\mathrm{cm}$ high $\times 2$-cm diameter) were placed in $23-\mathrm{mm}$ diameter test tubes which were kept vertical in an oven at $95^{\circ} \mathrm{C}$. The tubes were removed after $25 \mathrm{~min}$ and placed horizontally to let the cheese cylinder flow at room temperature. Flowability is the distance the leading edge of cheese has flowed when the flow has ceased.

\section{Uniaxial Compression Test}

Mechanical properties of the cheese samples were evaluated by a uniaxial compression test using at least five replicates each in an Instron (model 1130) universal testing machine. Cylindrical cheese specimens $(2 \mathrm{~cm}$ high $\times 2 \mathrm{~cm}$ diameter) were cut from the core of the cheese blocks. The specimens were compressed between stainless steel parallel plates lubricated with mineral oil at a deformation rate of $5 \mathrm{~cm} / \mathrm{min}$. The samples were equilibrated to room temperature $\left(\sim 22^{\circ} \mathrm{C}\right)$ before tests. Identical samples were also subjected to texture profile analysis (Friedman et al., 1963) using two successive $70 \%$ compressions between parallel plates with the same crosshead speed and test temperature as for uniaxial compression.

\section{Sensory Analysis}

Descriptive sensory analysis was performed by 35 trained panelists to evaluate the Cheddar cheese samples. Separate descriptor scales, each with its own descriptor-labeled anchor points and consisting of a semistructured linear scale characteristic of quantitative descriptive analysis (Meilgaard et al., 1991; Stone and Sidel, 1993), were selected and employed in the ballot. Appearance, flavor, body, and texture attributes were assessed. The mean score of each category was calculated and used in further analysis.

\section{Statistical Analysis}

The ANOVA (Minitab Release 10.51 Xtra, Minitab, Inc., State College, PA) was used for data analysis. Fisher's LSD multiple comparison at 0.05 of individual error rate was also performed for each measurement at all ages of cheeses.

\section{RESULTS AND DISCUSSION}

The ratio of chymosin-to-C. parasitica protease did not significantly affect cheese composition $(P>0.05)$ at $1 \mathrm{~d}$ after manufacture (Table 2). The results of PAGE for each type of cheese from d 1 to 120 are shown in Figure 1. In all samples, residual $\alpha_{\mathrm{s} 1}-\mathrm{CN}$ decreased over time at different rates (Figure 2), but the rate was especially pronounced in the first $60 \mathrm{~d}$. Cheese B (enzyme ratio $0: 1$ ) contained a higher residual $\alpha_{\mathrm{s} 1}-\mathrm{CN}$ than cheese A (enzyme ratio 1:0) at all ages. The patterns of hydrolysis differed for $\beta$-CN, as shown in Figure 2. The amount of $\beta$-CN in cheese A decreased only slightly over $120 \mathrm{~d}$. In general, the degree of hydrolysis of $\beta$ $\mathrm{CN}$ for all cheeses was less than that of $\alpha_{\mathrm{s} 1}-\mathrm{CN}$.

Most levels of hydrolysis of $\alpha_{\mathrm{s} 1}$-CN during maturation of the four cheeses were significantly different at each stage of maturation except for the following: $\mathrm{A}=\mathrm{C}$ and $\mathrm{B}=\mathrm{D}$ at $10 \mathrm{~d}, \mathrm{~B}=\mathrm{D}$ and $\mathrm{C}=\mathrm{D}$ at $30 \mathrm{~d}$, and $\mathrm{A}=\mathrm{C}$ and $\mathrm{C}=\mathrm{D}$ at $120 \mathrm{~d}(P>0.05)$. Hydrolysis of $\alpha_{\mathrm{s} 1}-\mathrm{CN}$ was significantly different among all cheeses at $60 \mathrm{~d}$ but not different at $1 \mathrm{~d}$. In contrast, significant differences were observed in residual $\beta$-CN even at $1 \mathrm{~d}$ and later except for the following: $\mathrm{C}=\mathrm{D}$ at all ages and $\mathrm{A}=\mathrm{D}$ at $10 \mathrm{~d}$ $(P>0.05)$.

As shown in Figure 3, the percentage of 12\% TCA soluble $\mathrm{N}$ increased with age but at a slightly different rate for each sample. Proteolysis as measured by soluble $\mathrm{N}$, was significantly different for all cheeses at all ages except that $\mathrm{B}=\mathrm{D}$, at $1 \mathrm{~d}, 10 \mathrm{~d}$, and $30 \mathrm{~d}$.

In all samples, $\mathrm{pH}$ decreased sharply during the first $10 \mathrm{~d}$ and then decreased gradually until $60 \mathrm{~d}$. After 60 $\mathrm{d}$, the $\mathrm{pH}$ increased at slightly different rates for each sample (Figure 4). There were also significant differ- 
Table 2. Composition of Cheddar cheeses $1 \mathrm{~d}$ after manufacture.

\begin{tabular}{llllllll}
\hline Cheese Type $^{1}$ & Moisture (\%) & MNFP (\%) & FDM (\%) & Salt (\%) & S/M (\%) & Initial pH & Total protein (\%) \\
\hline A & 37.82 & 55.53 & 51.07 & 1.38 & 3.66 & 5.15 & 39.29 \\
B & 37.78 & 55.56 & 51.43 & 1.38 & 3.66 & 5.13 & 38.83 \\
C & 37.71 & 55.12 & 50.03 & 1.40 & 3.72 & 5.16 & 39.46 \\
D & 37.59 & 54.94 & 50.34 & 1.39 & 3.71 & 5.12 & 38.92 \\
$P$-value & 0.358 & 0.077 & 0.052 & 0.486 & 0.265 & 0.135 & 0.999 \\
\hline
\end{tabular}

${ }^{1}$ See Table 1.

ences in $\mathrm{pH}$ among samples at all ages except between the following: $\mathrm{B}=\mathrm{C}$ at $1 \mathrm{~d}, \mathrm{~A}=\mathrm{D}$ and $\mathrm{B}=\mathrm{C}$ at $10 \mathrm{~d}, \mathrm{~A}$ $=\mathrm{C}$ and $\mathrm{B}=\mathrm{D}$ at $30 \mathrm{~d}, \mathrm{~A}=\mathrm{C}$ at $60 \mathrm{~d}$, and $\mathrm{B}=\mathrm{D}$ at $120 \mathrm{~d}$. The order of the cheeses tested according to the amount of soluble $\mathrm{N}$ produced and $\mathrm{pH}$ is: $\mathrm{B}>\mathrm{D}>\mathrm{C}>\mathrm{A}$.

Figure 5A to $\mathrm{C}$ shows the coefficient of determinations $\left(\mathrm{R}^{2}\right)$ between natural logarithm of hydrolysis of the caseins [i.e., $\ln (100 \%$ intact casein)], meltability, and hardness during maturation. The $\mathrm{R}^{2}$ were obtained by pooling together all measured values. The correlations obtained between hardness and hydrolysis of $\alpha_{\mathrm{s} 1}-\mathrm{CN}$ and between meltability and hydrolysis of $\beta$-CN were -0.792 and 0.714 , respectively (Figure 5A). However, as shown in Figure 5B, the correlations between meltability and hydrolysis of $\alpha_{\mathrm{s} 1}-\mathrm{CN}$ and between hardness and hydrolysis of $\beta$-CN were low ( 0.328 and -0.443 , respectively). The low correlation $\left(\mathrm{R}^{2}=0.108\right)$ between hydrolysis of $\beta$-CN and $\alpha_{\mathrm{s} 1}$-CN (Figure $5 \mathrm{C}$ ) indicates that independent control of cheese meltability and hardness is attainable. A slight negative correlation $\left(\mathrm{R}^{2}\right.$ $=-0.641$ ) between hardness and meltability (Figure 5C) is expected.

Meltability was significantly greater at all stages of maturation for cheese B compared with cheese A. The difference in meltability increased with age (Figure 6). The LSD multiple comparison showed that the melt- ability of each sample was significantly different except for the following: $\mathrm{B}=\mathrm{D}$ and $\mathrm{C}=\mathrm{D}$ at 10 and $30 \mathrm{~d} ; \mathrm{A}=$ $\mathrm{C}$ and $\mathrm{B}=\mathrm{D}$ at $60 \mathrm{~d}$; and $\mathrm{A}=\mathrm{C}, \mathrm{B}=\mathrm{D}$, and $\mathrm{C}=\mathrm{D}$ at $120 \mathrm{~d}$. The trend of higher meltability with higher $C$. parasitica enzyme agrees with Bogenrief and Olson (1995), who reported that hydrolysis of $\beta$-CN was greatly enhanced in Cheddar cheese by using the clotting enzyme from $C$. parasitica, and meltability was closely correlated with the extent of $\beta$-CN hydrolysis but not with the hydrolysis of $\alpha_{\mathrm{s} 1}-\mathrm{CN}$.

Flowability of cheeses changed with age in a manner similar to meltability (Figure 7). Flowability differed significantly except between these pairs: $A=C, A=D$, and $\mathrm{C}=\mathrm{D}$ at $10 \mathrm{~d}, 60 \mathrm{~d}$, and $120 \mathrm{~d}$. However, on d 30 there was only a significant difference between B and C.

Figure 8 shows typical uniaxial compression curves for different cheeses studied during maturation. The presence or absence of fracture point during compression seemed to depend on cheese type and age. Fracturability is the force at significant break in the curve during first bite. This parameter initially was called brittleness. It is the force recorded when a sample crumbles, cracks, or shatters (Pye, 1996). It was observed for cheese B at all ages, but not observed distinctly except at $1 \mathrm{~d}$ for all other cheeses and at 10 and $30 \mathrm{~d}$ for cheese A. It suggests that cheese B is more brittle

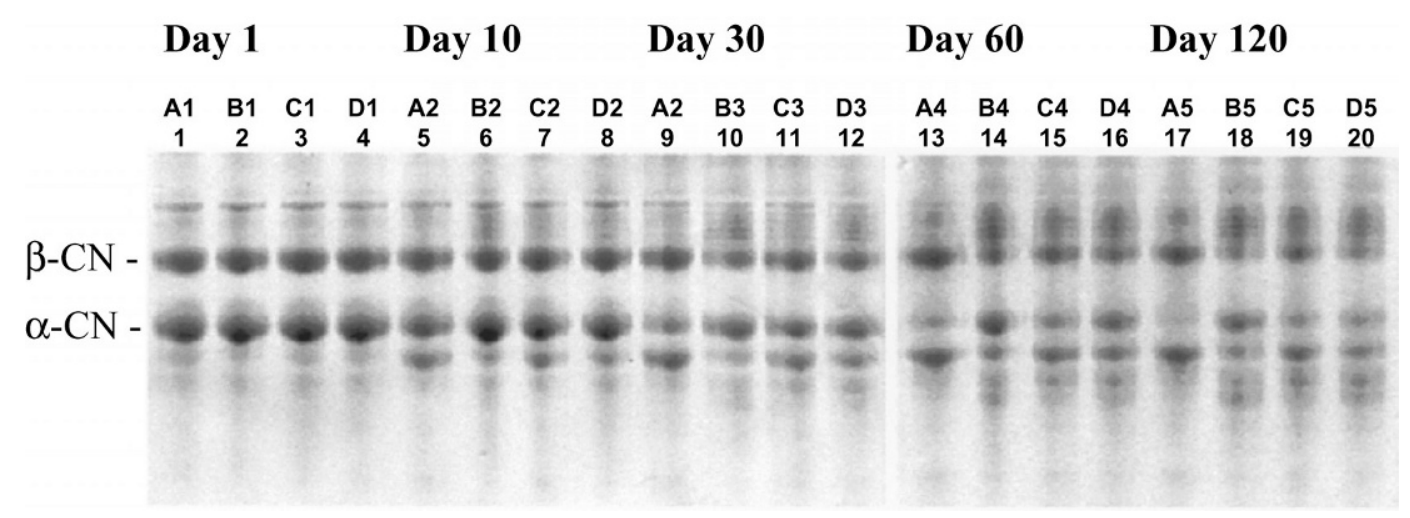

Figure 1. Pattern of casein hydrolyses of Cheddar cheeses made with different ratios of coagulants over time. Lanes, 1-4, indicate the 4 types of cheeses at 1-d; lanes 5-8, at 10-d; lanes 9-12, at 30-d; lanes 13-16, at 60-d; and lanes 17-20, at 120-d, respectively. Letters indicate the types of cheese, as defined in Table 1. 

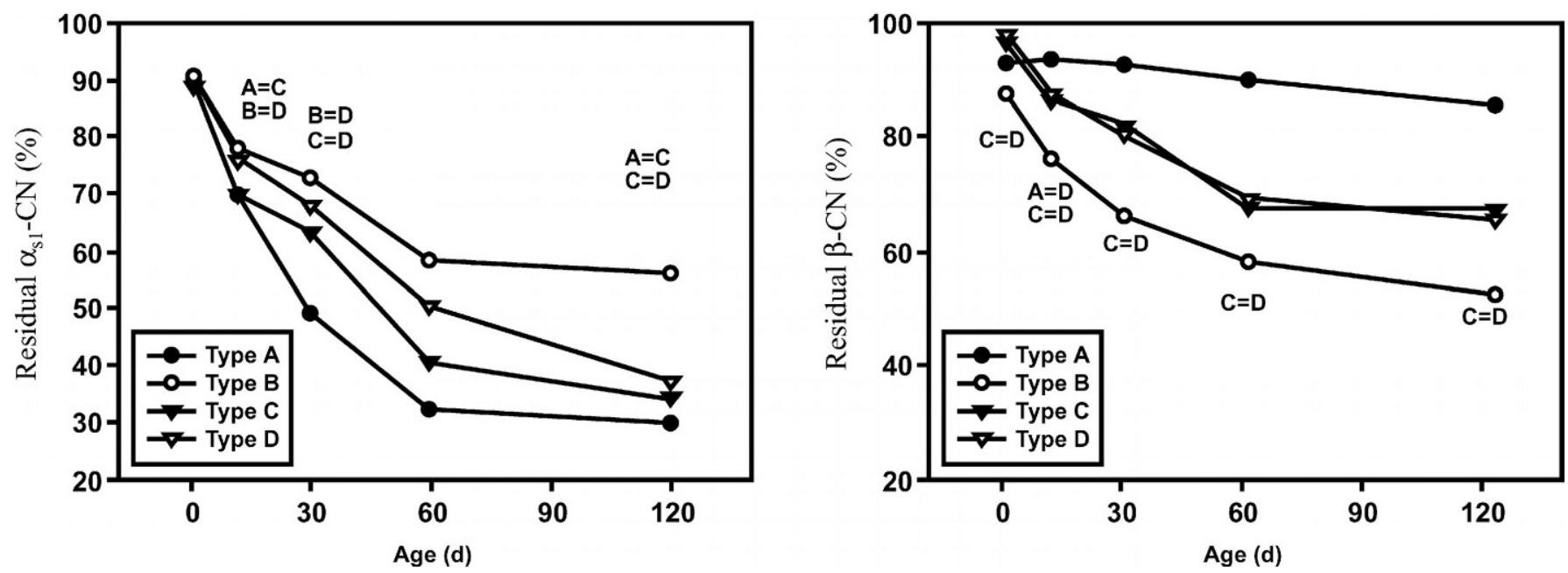

Figure 2. Hydrolysis of $\alpha_{\mathrm{s} 1}$-CN (on left) and $\beta$-CN (on right) of Cheddar cheeses made with different ratios of coagulants (see Table 1 for cheese type description). The residual amounts of caseins indicated the proportion, in reference to the intact amounts. Letters beside points indicate significance from multiple comparison.

than other cheeses with maturation. Fracturability of samples at $1 \mathrm{~d}$ were: $101.41 \mathrm{~N}, 122.90 \mathrm{~N}, 156.90 \mathrm{~N}$, and $158.58 \mathrm{~N}$ for cheeses $\mathrm{A}, \mathrm{B}, \mathrm{C}$, and $\mathrm{D}$, respectively. However, due to lack of homogeneity of components just after manufacture, no conclusion can be drawn based on 1-d test results. The higher the content of $C$. parasitica enzyme, the more the aging cheese tends to have fracture point during compression.

Our results support the observations of de Jong (1977) and Creamer and Olson (1982), i.e., a close relationship between the disappearance of $\alpha_{\mathrm{s} 1}$-CN and the magnitude of softening of Meshanger (a soft Dutch

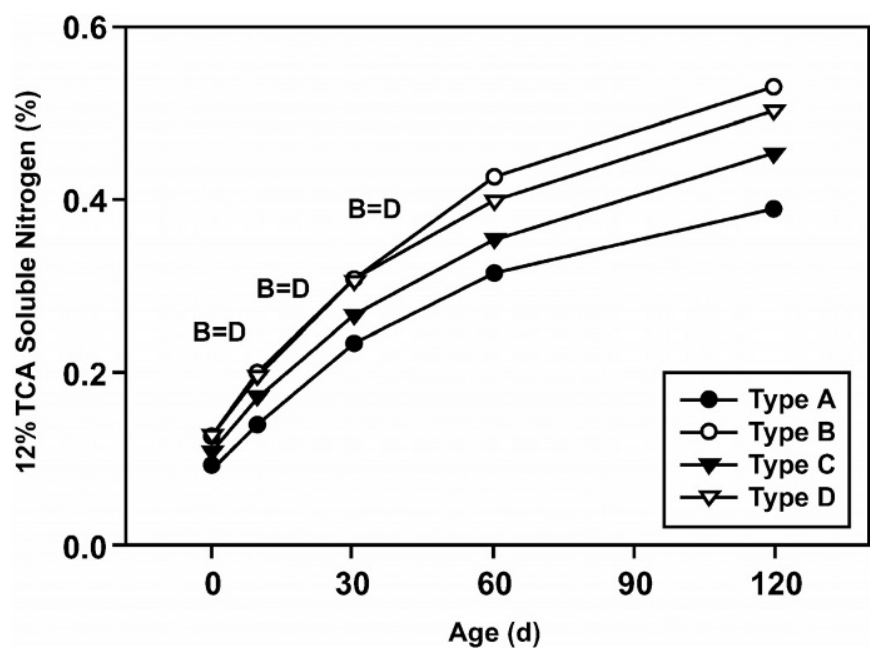

Figure 3. Profile of $12 \%$ TCA soluble nitrogen during maturation of the 4 types of cheeses (see Table 1 for cheese type description). Letters beside points indicate significance from multiple comparisons. cheese), and a good correlation between decrease in percent compression force at fracture point and the hydrolysis of $\alpha_{\mathrm{s} 1}-\mathrm{CN}$ of Cheddar cheese, but not related to that of $\beta-\mathrm{CN}$, respectively.

Hardness is the height of the force peak on first compression cycle, i.e., the first bite. It relates to the force within the mouth required to compress a substance between the molar teeth or between the tongue and palate (Pye, 1996). The degree of hardness of all samples decreased at very similar rates after $10 \mathrm{~d}$, but cheeses $\mathrm{B}$ and $\mathrm{C}$ showed higher degrees of hardness from $60 \mathrm{~d}$ on (Figure 9). The degree of hardness at $70 \%$

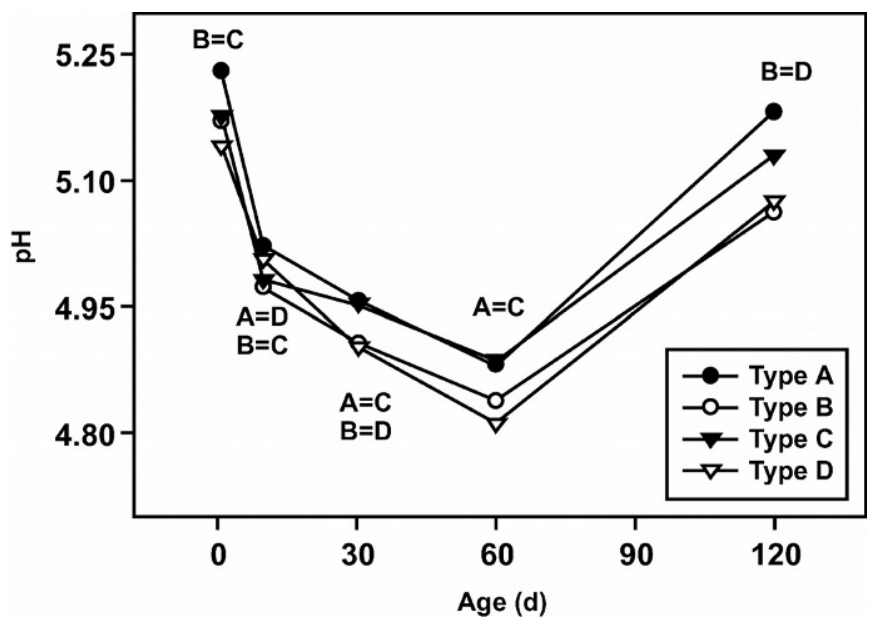

Figure 4. Profile of $\mathrm{pH}$ during maturation of 4 types of cheeses (see Table 1 for cheese type description). Letters beside points indicate presence or absence of significance between types of cheeses from multiple comparison. 

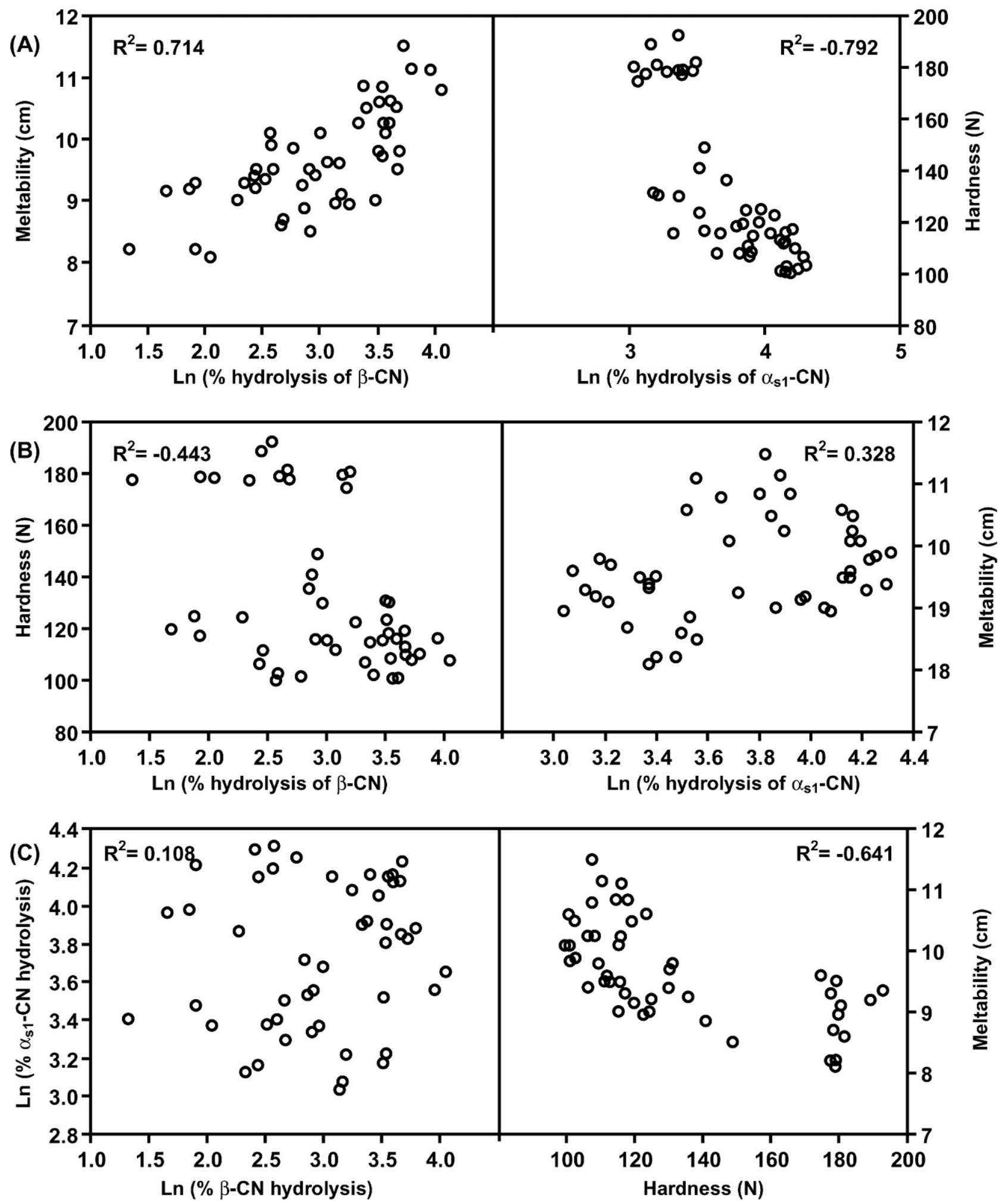

Figure 5A. Correlations between hydrolyses of $\alpha_{\mathrm{s} 1}{ }^{-} \mathrm{CN}$ and $\beta$-CN, meltability, and hardness (A and B) and between hydrolyses of $\alpha_{\mathrm{s} 1^{-}}$ $\mathrm{CN}$ and $\beta$-CN and, between meltability and hardness (C) during maturation, at 10, 30, 60, and $120 \mathrm{~d}(\mathrm{~A}$ and $\mathrm{B}$ ). The graphs were obtained from pooled data for all cheese types. 


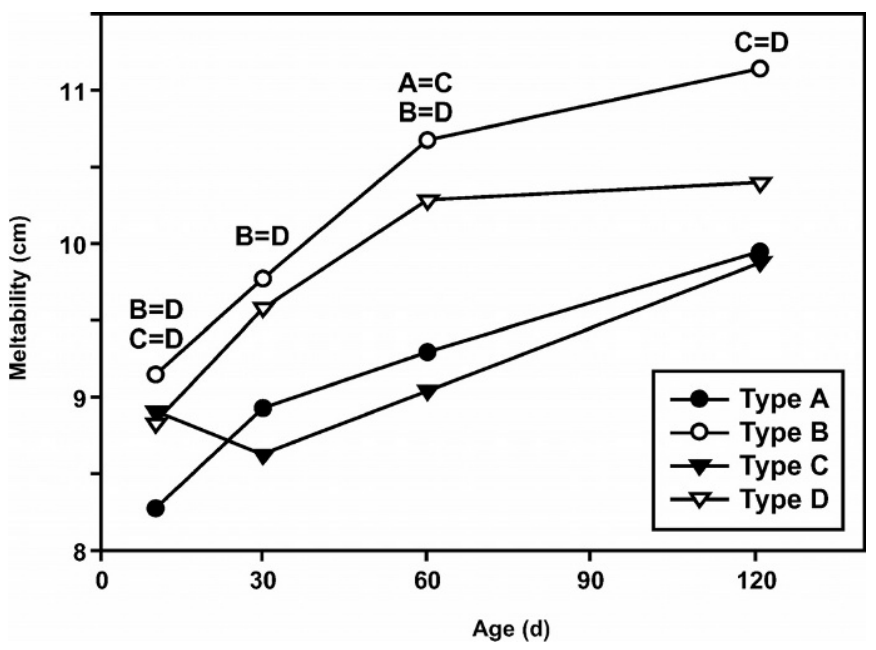

Figure 6. Meltability of Cheddar cheeses made with various ratios of coagulants (see Table 1 for cheese type description) in $95^{\circ} \mathrm{C}$ water bath for $5 \mathrm{~min}$. Letters besides points indicate no significance between types of cheeses from multiple comparison.

compression was significantly lower for cheese A (100\% chymosin) at 60 and $120 \mathrm{~d}$, respectively. In addition, cheese $\mathrm{C}$ appeared to be significantly harder than cheese $\mathrm{A}$ but equal to cheese $\mathrm{B}$. Cheese $\mathrm{D}$ seemed to be identical to cheese A in hardness. Compared with the trend of meltability, hardness seemed peculiar to the ages 60 and $120 \mathrm{~d}$. Substantial decreases in hardness were observed during the first $30 \mathrm{~d}$ of aging of cheeses $\mathrm{C}$ and D. At 60 and $120 \mathrm{~d}$, the hardness of all types of cheeses seemed to be stable.

Figure 10 shows no significant differences among cheeses at all three ages in terms of flavor intensity,

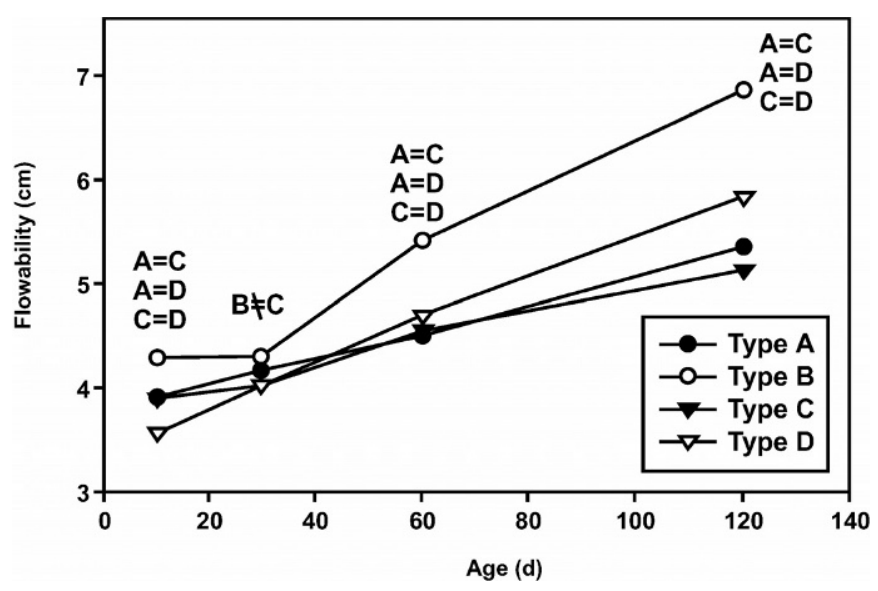

Figure 7. Flowability of Cheddar cheeses made with various ratios of coagulants (see Table 1 for cheese type description) in $95^{\circ} \mathrm{C}$ oven for $25 \mathrm{~min}$. Letters beside points indicate presence or absence of significance between types of cheeses from multiple comparisons. off-flavor intensity, and acceptability of appearance. Marked differences were found, however, with regard to bitter flavor intensity, firmness, and hardness during chewing. Cheeses B and D (made with $100 \%$ and $67 \%$ C. parasitica protease, repectively) exhibited higher levels of bitter flavor than cheeses A and C. Cheese A (made with $100 \%$ chymosin) was softer than cheeses B, $\mathrm{C}$, and $\mathrm{D}$ at 60 and $120 \mathrm{~d}$.

All samples at $30 \mathrm{~d}$ had a very mild cheese flavor, and several panelist comments indicated that cheese A was significantly weaker in acid and bitter flavor intensity than cheeses B and D. Cheese $\mathrm{C}$ tended to be slightly stronger than cheese A in both acid and bitter flavor. The difference in off-flavor intensity attributes were not statistically significant among the samples. Cheese B was generally perceived as the firmest. At 60 $\mathrm{d}$, cheeses $\mathrm{A}$ and $\mathrm{C}$ were weaker in acid and bitter flavors which correlated with slightly higher flavor acceptability scores. Cheese A was significantly weaker. The trend was similar at $120 \mathrm{~d}$.

There have been many reports that proteins giving bitter tasting enzymatic hydrolysates have a high average hydrophobicity (Guigoz and Solms, 1976). Sullivan et al. (1971) characterized bitter peptide, the residues 194 to 209 of the C-terminal sequence of $\beta$-CN (Ribadeau-Dumas et al., 1972; Guigoz and Solms, 1976). Hodges et al. (1972) and Richardson and Creamer (1973) isolated three bitter peptides that could be placed near the chymosin-sensitive 23 to 24 position in the $\alpha_{\mathrm{s} 1}$-CN sequence. Richardson and Creamer stated that no bitter peptides from $\beta$-CN could be detected. Hamilton et al. (1974) isolated a bitter peptide identified as the 46 to 67 fragment of $\beta$-CN from a commercial Cheddar cheese. Huber and Klostermeyer (1974) found the $\beta$ CN fragment 61 to 69 to be a bitter component in cheese.

Fractionation of hydrophobic peptide material from a Gouda-type cheese made with $S$. cremoris HP by Visser et al. (1983a, b), with further purification of all bitter fractions, resulted in the isolation of three peptides. The two major components were identified as bitter fragments from the $\mathrm{C}$-terminal part of $\beta$-CN, i.e., $\beta(193-$ $209)$ and $\beta$ (193-207) or $\beta(193-208)$. The third component presumably represents the 84 to 89 sequence of $\beta$-CN. They concluded that $\beta$-CN, and its $\mathrm{C}$-terminal region in particular, forms a principal source of bitter peptides.

\section{CONCLUSIONS}

Different combinations of chymosin and C. parasitica enzyme produced different degrees of hydrolysis of $\alpha_{\mathrm{s} 1^{-}}$ $\mathrm{CN}$ and $\beta$-CN in Cheddar cheese during aging which affects its rheological behavior (e.g., hardness and meltability). Two factors that cause variation in hydrolysis 


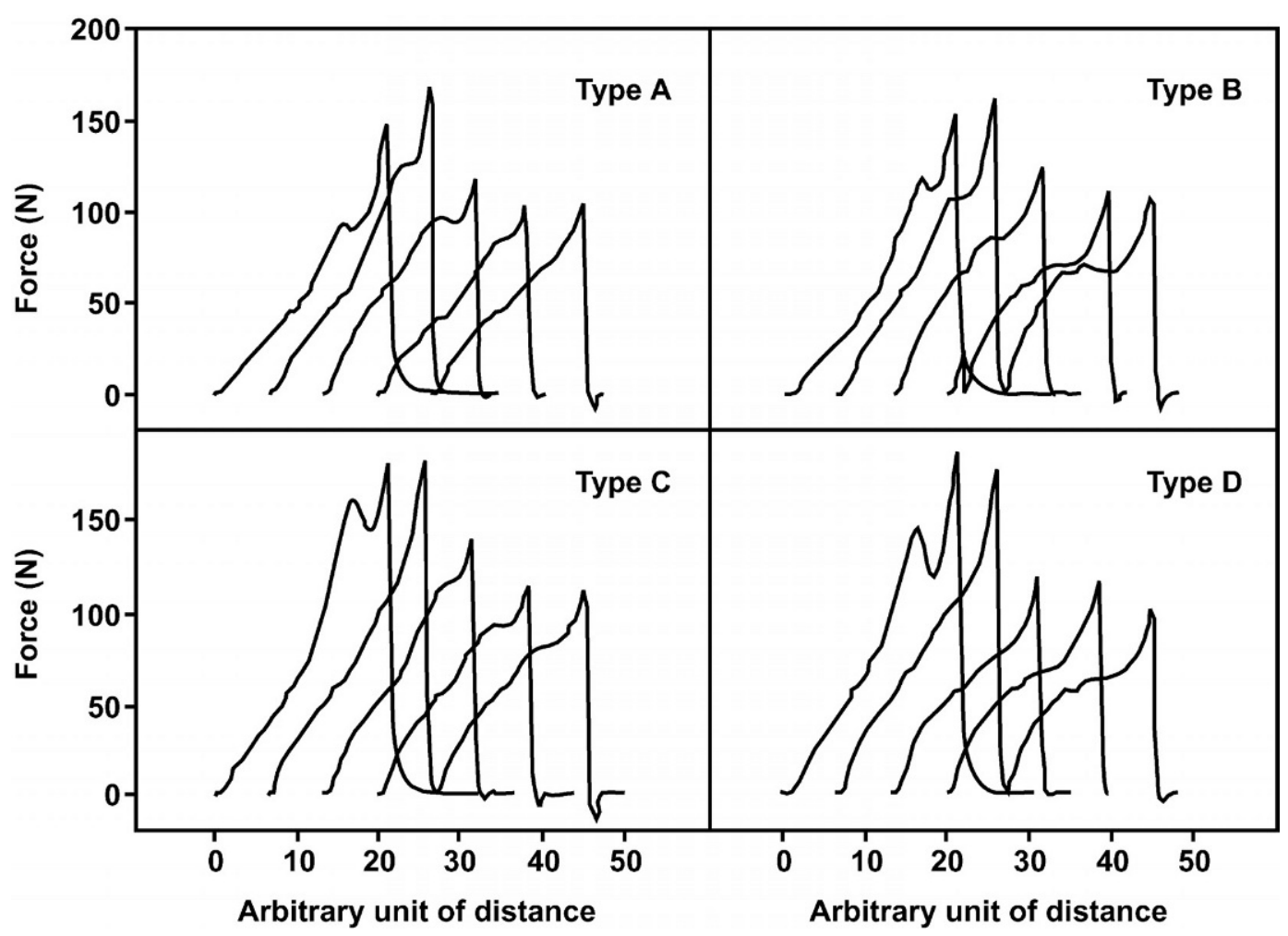

Figure 8. Force-distance profiles for $70 \%$ compression of Cheddar cheese types (see Table 1 for cheese type description). For each cheese type, the curves presented correspond to $1,10,30,60$, and $120 \mathrm{~d}$ from left to right, repectively.

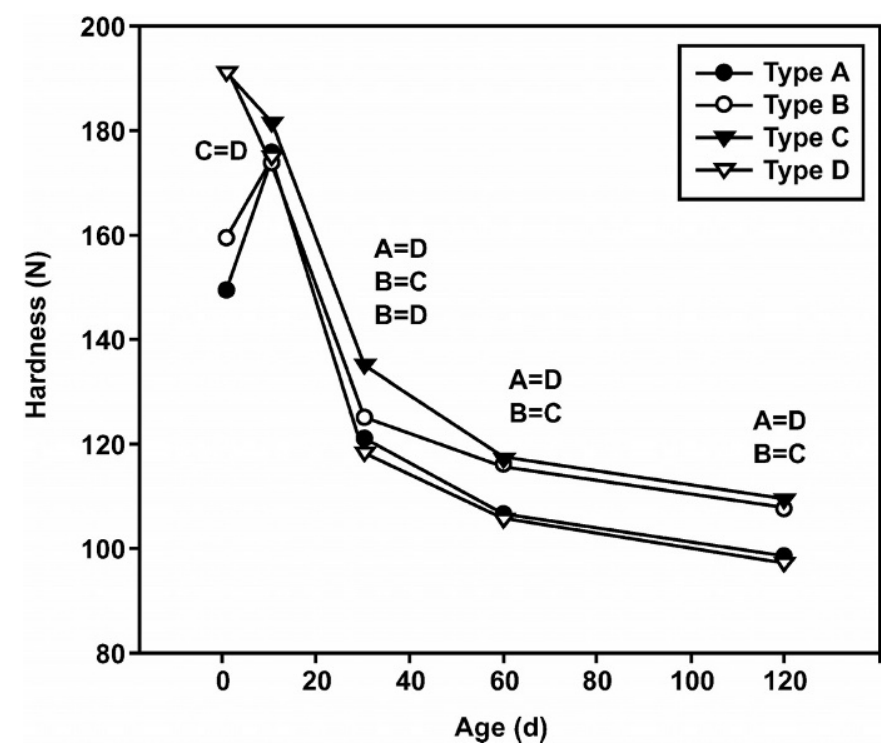

Figure 9. Hardness of four types of Cheddar cheeses made with various ratios of coagulants (see Table 1 for cheese type description) at $70 \%$ compression. Letters beside points indicate presence or absence of significance between types of cheeses from multiple comparison. of caseins by the two coagulants are: 1) the specificity of the peptide bonds to the enzyme and 2) the accessibility of the peptide bonds to the enzyme. The meltability and hardness of cheese B made with $100 \%$ C. parasitica protease was greater than cheese A made with $100 \%$ chymosin. The extent of $\alpha_{\mathrm{s} 1}$-CN hydrolysis correlated positively with cheese meltability and negatively with cheese hardness; these trends of meltability and hardness were reversed with the extent of $\beta$-CN hydrolysis.

Cheeses A (made with 100\% chymosin) and C (made with $67 \%$ chymosin) were weaker in acid and bitter flavors than cheeses B and D, which correlated with slightly higher flavor acceptability scores. Cheese $\mathrm{C}$ was found significantly harder by both the panel and Instron test than cheeses A and D (made with 67\% C. parasitica enzyme). However, the meltability and hardness of cheese $\mathrm{C}$ was not significantly different from cheeses A and D. The meltability of cheese B (made with $100 \%$ C. parasitica enzyme) was the highest. Cheese $\mathrm{C}$ was also hard, but its bitterness is a disadvantage. Therefore, a ratio of two coagulants in between those used for cheeses B and C (and quantities per Table 1) is recommended for manufacturing Cheddar cheese in order to control the meltability and hardness simultaneously without a significant level of bitterness. 

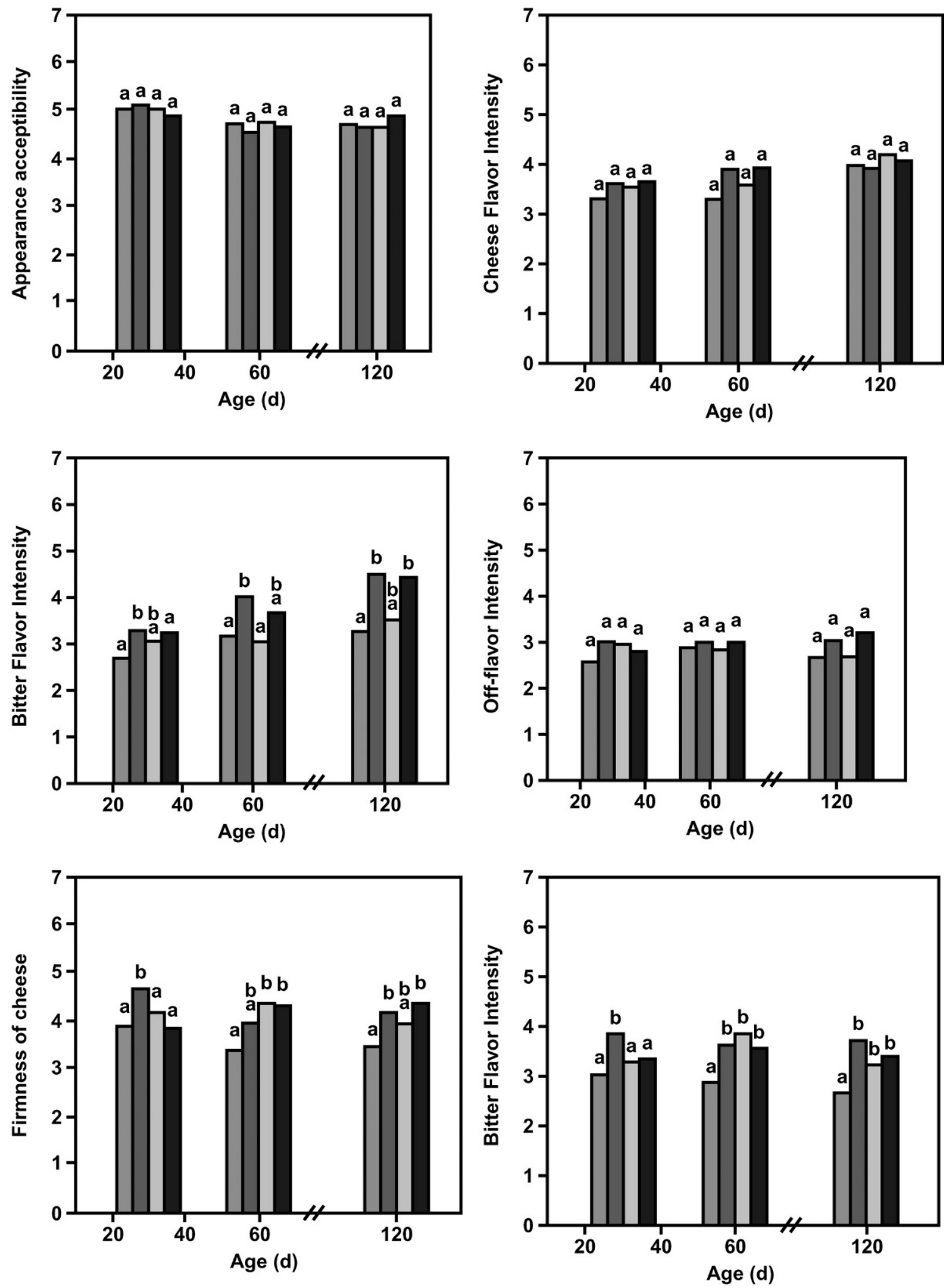

Figure 10. Seven-point descriptive sensory analysis scores for different sensory attributes of cheeses A, B, C, and D from left to right in each group of bars, respectively (see Table 1 for cheese type description). The bars designated by same lower case letters a and/or $\mathrm{b}$ over the bars represent statistical difference at $5 \%$ level. 


\section{REFERENCES}

Andrews, A. T. 1983. Proteinases in normal bovine milk and their action on caseins. J. Dairy Res. 50:45-55.

Blakesley, R. W., and J. A. Boezi. 1977. Short communication: A new staining technique for proteins in polyacrylamide gels using Commassie Brilliant Blue G250. Anal. Biochem. 82:580-582.

Bogenrief, D. D., and N. F. Olson. 1995. Hydrolysis of $\beta$-casein increases Cheddar cheese meltability. Milchwissenschaft 50:678682.

Bradley, R. L., Jr., E. Arnold, Jr., and D. M. Barbano. 1992. Page 433 in Standard Methods for the Examination of Dairy Products. 16th ed. R. T. Marshall, ed. Am. Publ. Health Assoc., Inc., Washington, DC.

Bynum, D. G., and D. M. Barbano. 1985. Whole milk reverse osmosis retentates for Cheddar cheese manufacture: chemical changes during aging. J. Dairy Sci. 68:1-10.

Creamer, L. K., and N. F. Olson. 1982. Rheological evaluation of maturing Cheddar cheese. J. Food Sci. 47:631-636, 646

De Jong, L. 1977. Protein breakdown in soft cheese and its relation to consistency: 2. The influence of the rennet concentration. Neth. Milk Dairy J. 31:314-327.

Friedman, H. H., J. E. Whitney, and A. S. Szczesniak. 1963. The Texturometer-a new instrument for objective texture. J. Food Sci. 28:390-396.

Green, M. L., S. Angal, and F. A. O. Marston. 1985. Cheddar cheesemaking with recombinant calf chymosin synthesized in Escherichia coli. J. Dairy Res. 52:281-286.

Guigoz, Y., and J. Solms. 1976. Bitter peptides, occurrence and structure. Chem. Senses Flavor 2:71-84.

Hamilton, J. S., R. D. Hill, and H. van Leeuwen. 1974. A bitter peptide from Cheddar cheese. Agric. Biol. Chem. 38(2):375-379.

Hodges, R., S. B. H. Kent, and B. C. Richardson. 1972. The mass spectra of some permethylated acethylpeptides. Biochim. Biophys. Acta 257:54-60.

Huber, L., and H. Klostermeyer. 1974. Isolation of a bitter peptide from the cheese "Butterkäse" and its identification. Milchwissenschaft 29:449-445.

Johnson, M. E., and N. F. Olson. 1985. A comparison of available methods for determining salt levels in cheese. J. Dairy Sci. 68:1020-1024.

McSweeney, P. L. H., and P. F. Fox. 1993. Page 341 in Cheese: Chemistry, Physics and Microbiology. Vol. 1. 2nd ed. P. F. Fox, ed. Chapman and Hall, London, UK.
Meilgaard, M., Civille, G. V., and B. T. Carr. 1991. Sensory evaluation techniques. CRC Press, Boca Raton, FL.

O'Sullivan, M., and P. F Fox. 1991. Evaluation of microbial chymosin from genetically engineered Kluyveromyces lactis. Food Biotechnol. 5:19-32.

Pye, J. 1996. Gelatin—-the scientific approach to product quality. Food Aust. 48:414-416.

Richardson, B. C., and L. K. Creamer. 1973. Casein proteolysis and bitter peptides in Cheddar cheese. NZ. J. Dairy Sci. Technol. 8:46-51.

Richardson, G. H., and R. T. Marshall. 1985. Page 382 in Standard Methods for the Examination of Dairy Products. 16th ed. Am. Publ. Health Assoc., Inc., Washington, DC.

Shalabi, S. I., and P. F. Fox. 1987. Electrophoretic analysis of cheese: comparison of methods. Irish J. Food Sci. Technol. 11:135-151.

Stone, H., and J. L. Sidel. 1993. Sensory evaluation practices, Academic Press, San Diego, CA.

Sullivan, J. J., F. G. Kieseker, and G. R. Jago. 1971. The effect of $\mathrm{pH}$ and starter culture on the bitterness of peptide extractions of a tryptic digest of casein. Aust. J. Dairy Technol. 26:111-112.

Tam, J. J., and J. R. Whitaker. 1972. Rates and extents of hydrolysis of several caseins by pepsin, rennin, Enthothia parasitica protease and Mucor pusillus protease. J. Dairy Sci. 55:1523-1531.

Van Sylke, L. L., and W. V. Price. 1979. Page 4760 in Cheese. Ridgeview Publishing Co., Atascasero, CA.

Vanderpoorten, R., and M. Weckyx. 1972. Breakdown of casein by rennet and microbial milk-clotting enzymes. Neth. Milk Dairy J. 26:47-59.

Visser, S., G. Hup, F. A. Exterkate, and J. Stadhoulders. 1983a. Bitter flavour in cheese. 2. Model studies on the formation and degradation of bitter peptides by proteolytic enzymes from calf rennet, starter cells and starter cell fractions. Neth. Milk Dairy J. 37:169-180.

Visser, S., K. J. Slangen, G. Hup, and J. Stadhoulders. 1983b. Bitter flavour in cheese. 3. comparative gel-chromatographic analysis of hydrophobic peptide fractions from twelve Gouda-type cheeses and identification of bitter peptides from a cheese made with Streptococcus cremoris strain HP. Neth. Milk Dairy J. 37:181192

Yun, J. J., L. J. Kiely, P. B. Kindstedt, and D. M. Barbano. 1993. Mozzarella cheese: impact of coagulant type on functional properties. J. Dairy Sci. 76:3657-3663. 